\title{
The relationship between number of retail-credit accounts and response rates
}

\author{
Y. Jordaan*, T.G. Kotzé and H. Louw \\ Department of Marketing and Communication Management, University of Pretoria, \\ Pretoria 0020, Republic of South Africa \\ bws1@maties.sun.ac.za
}

Received March 2004

\begin{abstract}
In South Africa, some of the bigger credit issuers operating in the direct marketing environment, specifically non-bank, personal finance companies, have complained that they are not seeing the return-on-investment they have come to expect from their direct mail campaigns, due to poor direct mail response rates. Low response rates have been encountered even though the market segment in which these companies are operating, has shown growing demand. With an increase in mailing costs and fierce competition in the direct marketing industry, lenders are constantly looking for ways to improve the effectiveness and profitability of their mailing campaigns. The approach followed was to analyse the response rate of a mailing campaign, and through regression analysis, determine the relationship between the number of active retailcredit accounts held and response rates. This was done against the backdrop of segmentation opportunities and an increasingly credit-active South African population. The results indicate that, in the personal finance and loan marketing environment, there is a positive linear relationship between the number of active retail accounts held by prospective clients and the response rates to credit-related marketing offers. Finally, the implications for direct marketing companies are discussed, limitations presented and future research opportunities outlined.
\end{abstract}

*To whom all correspondence should be addressed.

\section{Introduction}

Direct marketing evolved with the aim of establishing and maintaining long-term, structural, direct relationships between a supplier and its customers (Vriens, Van der Scheer, Hoekstra \& Bult, 1998: 323-324). A relationship develops through regular interaction, in which both parties respond to one another's actions. In direct marketing this interaction is accomplished through direct communication and/or direct distribution. Data and the database play an important role in this relationship in that large amounts of resources are expended on data collection, regular data updates and data analysis before the customer is even contacted (Forcht \& Cochran, 1999: 189).

Direct mail, as a form of direct marketing, has many advantages over other media: for instance, direct mail can engage in precision targeting to a greater degree than other media; it offers the opportunity to personalise; and there is greater flexibility with regard to formats, timing and testing (Volman, Jordaan \& Bird, 2003: 278). However, the relatively high cost per potential customer, compared to that of alternative media, requires sufficient response rates to ensure profitable implementation. It is thus important to develop ways to improve the effectiveness of direct mail campaigns (Vriens et al., 1998: 324).

The method of marketing most often used by credit issuers is direct marketing, more specifically direct mail. Many issuers find trying to obtain a prospect list that generates a response rate in excess of 1 per cent, frustrating. There is no magic formula for predicting an average, or typical, response rate. Many sources have, however, quoted that 2 per cent is an average direct mail response rate (Souccar, 2000: 1; Bernstel, 2000: 28; Lucas, 2000: 35). Response rates also tend to differ across industries. Normal responses can easily vary from 0,1 per cent (not unusual in insurance or offers in print media), to 50 per cent or more, when very targeted, relevant mailings are sent to long-standing customers (DMA, 2000; Thomas \& Housden, 2002: 130).

In the United States of America alone, 3,5 billion credit-card solicitations were mailed during 2000 , but the average response rate dropped to 0,6 per cent (Linsley, 2001: 11). Mail Monitor, a national direct mail credit-card tracking system, recorded this response rate average as an all-time low compared to the response rates for the preceding years, viz 0,7 per cent (Albro \& Linsley, 2001: 11). These figures mirror the trend emerging from a study conducted by BAIGlobal in the United States, which show a gradual decline in direct mail response rates from 2,8 per cent in 1992, to 1 per cent in 1999, to 0,6 per cent in 2001 (Lach, 2000: 26; Schultz, 2002).

Regrettably there is no empirical research on the size of the direct marketing industry in South Africa, making it difficult to gain an idea of the benchmarks and norms in the industry, and to relate the relevant companies' performances against those of the industry. Based on best estimates of the market size, the catalogue mail-order market alone is estimated to be worth R1,5 billion annually, with the broader direct mail industry estimated at anything between R4 billion and R6 
billion (DMA, 2000). Although the current climate is perceived as challenging for credit marketers in South Africa, many want to strike a balance between low response rates and increased spending. The purpose is to enhance demographic-based prospect lists to enable better tailoring of a credit offer to a prospective credit-card holder.

The aim of this study is therefore to determine whether there is a relationship between the number of active retail accounts which individuals hold (as reflected by the credit bureaus) and the response rate to loan-type credit-related direct mail offers. If there proves to be a significant relationship, then marketers of these types of offers can look forward to new segmentation approaches based on specific credit characteristics.

\section{Segmentation opportunities}

Most companies now realise that the mass marketing approach is no longer feasible and have therefore resorted to grouping customers who exhibit similar characteristics and behaviours (Dibb, 1998: 394). This process is known as segmentation and refers to the process by which marketers divide the market into distinct groups in the belief that developing different offerings for some or all of these groups, will increase profitability (Hoek, Gendall \& Esslemont, 1996: 26). It is further posited by Hoek et al. (1996: 26) that segmentation can only be useful to marketers if it enables them to choose between different options. Nord and Peter (in Hoek et al., 1996: 26) have commented that segmentation must help marketers identify different response groups, which have uniform and stable responses to a particular set of marketing variables. This can, for example, enable marketers to target segments using different promotional media.

Traditional methods of segmentation rely heavily on geodemographic variables as well as on lifestyle or psychographic variables (Schoenwald, 2001: 34). A wellknown method in South Africa, that makes use of the aforementioned variables, is the Living Standards Measure (LSM) segmentation system. The LSM is an attempt to segment the South African market based on the quantification of ownership of durable goods and the use of certain services (Lamb, Hair, McDaniel, Boshoff, \& Terblanché, 2004: 50). However, research in the financial services and credit markets highlights a number of significant barriers to the implementation of current segmentation schemes. These barriers range from weaknesses in customer data and inappropriate organisational structure, to lack of marketing orientation and difficulties in obtaining a fit within the existing distribution structure (Meadows \& Dibb, 1998: 266).

Both income and social class have been studied as major determinants of buying behaviour in general (Paden, 1996: 2). While demographic information can help to classify and perhaps define the likelihood of purchasing, other data (such as credit-bureau data) may be needed to help understand actual buying behaviour. Two demographic profiles may look very alike at first, although they are in fact quite different. Both may have R120 000-00 per annum household incomes, a family, a house and two cars. When the credit characteristics of these individuals are analysed, however, it is easy to tell which individual is likely to have active credit lines (retail accounts), who is more likely to open new lines of credit, and what each person's spending and debt repayment tendencies are. These characteristics typically include the number and type of retail accounts (revolving, installment, open balance or utility), age of accounts, monetary value (opening balance) of credit, payment history and public-record information. More importantly, an analysis of these characteristics can help to predict which person is most likely to accept and use a new line of credit (Ibis, 1991: 39).

There are many companies working to benefit from these issues, including the credit bureaus. For example, in the United States, Equifax Inc, one of the larger credit-bureaus, has purchased the consumer information division of R.L Polk and Co, a provider of consumer demographic and lifestyle information (Souccar, 2000: 2). Experian, another major bureau, developed an Insource Database containing extensive consumer marketing lists and data enhancement services. The Insource database contains demographic information combined with information such as consumers who are most likely to respond to a credit card offer (Experian, 2004). In South Africa a similar trend is emerging i.e. to use credit (bureau) data to supplement traditionally demographic segmentation models. This is data information pertaining to how many retail accounts people have and how they use these accounts.

Current high postal rates make blanket mailings prohibitively expensive and direct mailing companies have fewer rands to spend on any type of prospecting. Each rand spent must provide better returns. What geo-demographics offer credit grantors, for example, is merely that a community has an average household income of $\mathrm{Rx}$ per annum. Thus, as Ibis (1991: 39) remarked, the aggregated data does not indicate who is above average income, who is spending the money or how they are spending it. Demographic data does not allow these people to be sorted by their individual credit habits and characteristics, but only by group or aggregated characteristics. This aggregated data, obtained mostly from census data, has been used in the past to compile lists containing names of prospects who would seem most credit-worthy. The result is that the best prospects tend to have their mail boxes overflowing with credit-related offers. Eventually consumers become immune to these kinds of offers (Lucas, 2000: 33). The general decline in response rates to direct mail credit offers could be attributable to the over-soliciting of certain market segments to the exclusion of others (Strumello, 2000: 4; Martien \& Morgan, 2002: 2).

\section{Credit customers and response rates}

Previous research on credit usage has focused on demographic descriptions of credit customers in general terms, but few have focussed specifically on retail credit customers and their use of credit. Previous studies have also relied heavily on self-reported questionnaires, which may or may not accurately reflect actual usage. Consumer credit research can generally be grouped into two categories: longitudinal data on credit usage (periodic data normally 
gathered via surveys and census data), and factors determining consumer credit behaviour (Paden, 1996: 3).

A study conducted by Bank Advertising News in the United States of America, investigated credit solicitation and response rates among a random sample of 383 consumers. The results indicated that over 60 per cent of direct mail credit-card solicitations go unopened. Middle-aged respondents (aged 24 to 44) were the most heavily solicited, receiving approximately 10 solicitations per month. They were however, the least likely to open these solicitations statistically 10 to 20 per cent lower than all other age groups (Strumello, 2000: 4).

This result correlates with another study (as reported by Sharpe, 1997) conducted on the debt and credit profiles of two age groups in the United States. The findings revealed some interesting statistics, which in turn could help to put debt levels and response rates into context. Mean debt and credit values indicated that the younger group owed more in each debt category (consumer debt, mortgage debt, household debt, other debt) and had a much larger proportion in mortgage debt. More than half of the debt held by the older group was in the 'other debt' category (51 per cent versus 21 per cent). Qualified credit for the younger group was higher than that for the older group (Sharpe, 1997: 210). Their findings prove that the younger age group in this particular case exhibited generally higher levels of debt. Even younger (below age 24), less-educated, and lower-income consumer groups, all of which typically comprise the emerging market, showed high response rates to solicitations, as one would expect, but consistently received the least amount of solicitations. The conclusion Sharpe (1997) drew was that the low response rates may be more of an effect than a cause of such marketing strategies. This view by Sharpe is further supported by Kaynak, Kucukemiroglu and Ozmen (1995: 52). They allege that in recent years, economic pressures, heightened competition, rapid technological developments, and a decline in consumer purchasing power have paved the way for a change in the credit marketing industry.

Several factors are influencing this change and transformation. Firstly, the over-extended credit-cardholding consumers, mainly in developed wealthy societies, who took on a significant amount of household debt in the 1980s, have now reduced their credit card spending significantly. Secondly, non-bank financial institutions have intensified their focus on existing credit-card customers. An example of such developments in South Africa is when Woolworths Holdings, the food and fashion retailer, expanded its financial services division in a joint venture with Mercantile Bank to launch a Visa-branded credit card into the local market. In April 2000, Woolworths linked up with Nedcor Investment Bank in its first official foray into unit trusts. This is in line with international trends where retailers with well-established brands, such as Tesco in the United Kingdom, offer financial products" (Von Lieres, 2000).

Thirdly, consumer advocates have criticised high credit fees and interest rates and what they describe as a host of hidden charges. Fourthly, an attitudinal and behavioural change is occurring in banking organisations towards the issuing of credit cards, due to saturating consumer demand. Statistics also reveal that the more retail-credit cards and retail accounts consumers already hold, the more likely they are to receive solicitations. It was also found that consumers holding five or more retail cards were most likely to open and respond to their solicitations. The assessment was that this segment is likely to be more debt-burdened, with a greater awareness of their credit-card balances and, consequently, in search of lower rates (Strumello, 2000: 4).

In South Africa the credit-active population is increasing rapidly. Table 1 reflects a few prominent statistics (in nominal terms) of the past five years, stressing this growth. Household credit alone grew by 6,7 per cent from 2001 to 2002 and by 11,7 per cent from 2002 to 2003 . Instalmentcredit sales alone, escalated by 29 per cent from 2002 to 2003 (SARB, 2004: S-22).

\section{Table 1: South African household credit}

\begin{tabular}{l|c|c|c|c|c}
\hline & $\begin{array}{c}\text { Household } \\
\text { credit } \\
\text { R millions }\end{array}$ & $\begin{array}{c}\text { Instalment } \\
\text { sale credit } \\
\text { R millions }\end{array}$ & $\begin{array}{c}\text { Leasing } \\
\text { finance } \\
\mathbf{R} \\
\text { millions }\end{array}$ & $\begin{array}{c}\text { Mortgage } \\
\text { advances } \\
\mathbf{R} \\
\text { millions }\end{array}$ & $\begin{array}{c}\text { Other } \\
\text { loans } \\
\text { and } \\
\text { advances } \\
\text { R } \\
\text { millions }\end{array}$ \\
\hline 1999 & 262149 & 52364 & 22081 & 203358 & 225691 \\
\hline 2000 & 286826 & 57068 & 24151 & 226269 & 236416 \\
\hline 2001 & 312071 & 64901 & 30069 & 259162 & 260852 \\
\hline 2002 & 333265 & 76619 & 31329 & 286002 & 269217 \\
\hline 2003 & 372400 & 89209 & 37315 & 329234 & 291428 \\
\hline
\end{tabular}

Source: SARB. 2004. Quarterly Bulletin, March: S-22.

The category 'other loans and advances', exhibited a growth of 43 per cent from 1997 to 2001 . This growth implies that the remaining viable market segments that can be targeted are becoming smaller, as the market is increasingly saturated with credit. Some consumer segments may already be overexposed in terms of their credit. This highlights the fact that many companies are not seeing the return-on-investment they have come to expect from their direct mail campaigns due to poor direct mail response rates. Instead of this approach, and in view of the increasing number of companies that use direct mail, it is important to develop methods to improve response rates or to analyse credit characteristics to predict which people are more likely to accept and use a new line of credit.

\section{Research methodology}

With the level of demographic information available in South Africa, direct credit marketing companies will possibly more resort to alternative means of enriching their existing data. This would include making use of credit (bureau) data and individual credit characteristics. Together with this the companies have to obtain a balance between low response rates and the cost of tailoring a credit offer to a prospective card holder. The objective of this study is therefore to determine whether there is a relationship between the number of active retail accounts held by individuals (as reflected by the credit bureaus) and the response rate to loan-type credit-related direct mail offers. The following hypothesis was set: 
$\mathrm{H}_{1}$ : In the personal finance and loan direct marketing environment, the number of active retail accounts ${ }^{1}$ held by prospective clients will have a positive linear relationship with the response rates to credit-related marketing offers in the form of a 'convenience cheque'.

Convenience cheques consist of up to three pre-printed cheques attached to a personalised, persuasive letter encouraging the prospective client to cash the cheque as a loan. The sponsor aims its offers to a market at a level between that of the micro-lenders and the banks (secured loans). The sponsor of the study is one of the biggest personal finance companies in South Africa (hereafter referred to as PFCo), and an issuer of personal loans between the value of R2 000-00 and R12 000-00 in the form of a "convenience cheque". The product offerings comprise unsecured short- to medium-term loans. PFCo is a direct marketing company that mails in excess of 500000 product offerings per annum.

The sample for this survey was drawn by randomly selecting prospects from PFCo's mailing list using the following parameters:

- $\quad$ Aged from 25 to 59;

- Non-existent clients (de-duplicated against previous responders existing in the current database);

- De-duplicated against a list of surnames to exclude staff and employees.

Remaining prospects were then 'pre-screened' in terms of their credit worthiness (based on their credit bureau score) and the mail file of 100000 was filtered down to 96987 prospects. An offer (an unsecured loan to a value of between R2 000-00 and R12 000-00) was sent to these 96987 prospects. A mailer maturation period of three months was allowed, during which the responses of the mailer were tracked and flagged. The effective response rate was 1,51 per cent (1 467 respondents). The original mail file was then handed to Information Trust Corporation (ITC), the largest credit bureau in South Africa. The latter was requested to match the individuals in PFCo's mail file to ITC's database by using the identification numbers, initials and surname of the individuals in the mail file as the common denominator. The ITC then extracted retrospectively for each of these individuals, in aggregated format, the number of active retail accounts held by the prospects at the time when the mail packs were sent out. Once the data had been appended to the mail file, the file was split into groups according to the number of active retail accounts, to enable comparison. With retail accounts being the independent variable (X), the groups were identified as people with $0,1,2,3,4,5,6,7$ and 8 or more active retail accounts. Table 2 presents the counts of the number of responders and non-responders for each retail account group.
Table 2: Counts of responders and non-responders

\begin{tabular}{l|c|c|c|c|c|c|c|c|c}
\hline $\begin{array}{c}\text { Number of } \\
\text { active } \\
\text { retail } \\
\text { accounts }\end{array}$ & $\mathbf{0}$ & $\mathbf{1}$ & $\mathbf{2}$ & $\mathbf{3}$ & $\mathbf{4}$ & $\mathbf{5}$ & $\mathbf{6}$ & $\mathbf{7}$ & $\mathbf{8 +}$ \\
\hline Responders & 245 & 463 & 349 & 188 & 114 & 55 & 31 & 13 & 9 \\
\hline $\begin{array}{l}\text { Non- } \\
\text { responders }\end{array}$ & 21492 & 39986 & 19367 & 8569 & 3479 & 1519 & 665 & 257 & 186 \\
\hline
\end{tabular}

Finally the response rate for each group was calculated (dependent variable Y). Table 3 indicates the response rates for the groups of active retail account holders.

Table 3: Response rate percentages

\begin{tabular}{c|c}
\hline $\begin{array}{c}\text { Count of total active retail accounts } \\
(\mathbf{X})\end{array}$ & Response rate $\%\left(\mathbf{Y}^{*}\right)$ \\
\hline 0 & 1,12711 \\
\hline 1 & 1,144651 \\
\hline 2 & 1,770136 \\
\hline 3 & 2,146854 \\
\hline 4 & 3,172836 \\
\hline 5 & 3,494282 \\
\hline 6 & 4,454023 \\
\hline 7 & 4,814815 \\
\hline 8 or more & 4,615385 \\
\hline
\end{tabular}

$*$ Response rate $\%$ calculated as the number of responders divided by the total number of responders and non-responders (see Table 2).

Regression analysis was used to investigate the relationship between the number of active retail accounts and response rates. When the observed values of $X$ are used to estimate or predict corresponding Y values, the process is called simple prediction. Simple (and multiple predictions) are made using regression analysis (Willemse, 1990: 161). $\mathrm{H}_{1}$ was tested at a 5 per cent significance level to determine whether there is enough evidence to infer a linear relationship between the number of active retail accounts and response rates. The standard error of estimate, the t-test of the slope and the coefficient of determination $\left(\mathrm{R}^{2}\right)$ were used to assess the regression's model fit.

\section{Results}

In regression analysis involving one dependent and one independent variable, the individual values are plotted on a two-dimensional graph called a scattergram. Figure 1 indicates a positive linear relationship between the number of active retail accounts and response rates.

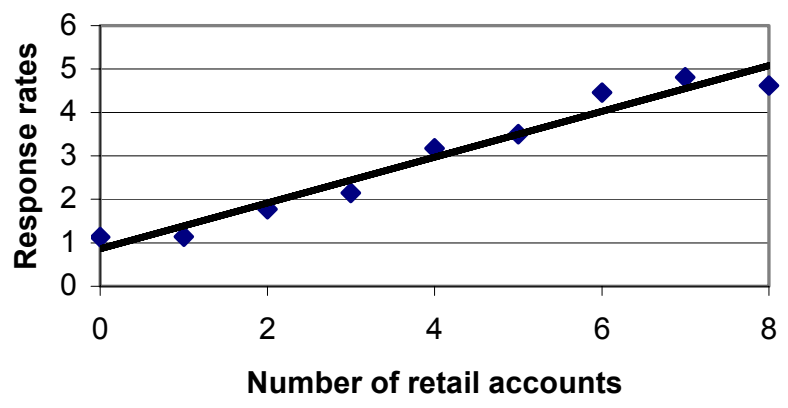

Figure 1: Scattergram of variables
${ }^{1}$ Active retail accounts - these include instalment, revolving credit and open-balance retail accounts, eg. a clothing account. 
The above scattergram indicated a linear relationship between the variables, enabling simple linear regression analysis. Table 4 presents the results from this regression performed on the dataset.

Table 4: Regression statistics

\begin{tabular}{|c|c|c|c|c|}
\hline \multicolumn{2}{|c|}{ Multiple R } & \multicolumn{2}{|l|}{0,978346151} & \\
\hline \multicolumn{2}{|c|}{ R square } & \multicolumn{2}{|l|}{0,957161192} & \\
\hline \multicolumn{2}{|c|}{ Standard error } & \multicolumn{2}{|l|}{0,327016859} & \\
\hline \multicolumn{2}{|c|}{ Observations } & \multicolumn{2}{|l|}{9} & \\
\hline & Coefficients & $\begin{array}{c}\text { Standard } \\
\text { error }\end{array}$ & t Stat & p-value \\
\hline Intercept & 0,859201733 & 0,200996431 & 4,274811 & 0,003679258 \\
\hline $\begin{array}{l}\text { Retail } \\
\text { accounts }\end{array}$ & 0,5279799 & 0,042217695 & 12,50613 & 0,00000482 \\
\hline
\end{tabular}

The smallest value that the standard error of estimate can assume is zero and represents a measure of the variation around the fitted line of regression. The standard error of this regression model is 0,327 , indicating a very good fit as well as the analytical and forecasting value of the linear model. The value of the test statistic is $t=12,50613$, with a $p$ value of 0,00000482 ( 5 per cent significance level). There is overwhelming evidence in favour of an inference that a linear relationship exists, i.e. the number of active retail accounts definitely affects the response rates. Although there is enough evidence to infer that there is a linear relationship, it is useful to measure the strength of this relationship. The statistic that performs this function is the coefficient of determination $\left(R^{2}\right)$. The higher the value of $R^{2}$ (closer to 1), the better the model fits the data. $\mathrm{R}^{2}$ is 0,957161192 , indicating that 95 per cent of the variation in the response rates is explained by the variation in the number of retail accounts. It is important to note that $\mathrm{R}$ square may be an inflated figure because the regression analysis was conducted on groups (number of retail accounts) and not on an individual level. Further, the independent variable (number of retail accounts) did not include consumer psychographics. Nevertheless, since all of the above findings were significant, support is found for $\mathrm{H}_{1}$, indicating that in the personal finance and loan direct marketing environment, the number of active retail accounts held by prospective clients has a positive linear relationship with the response rates to credit-related marketing offers in the form of 'convenience cheques'.

\section{Implications and limitations of the study}

A number of key issues have changed the structure of the consumer marketplace, as well as the behaviour and expectations of consumers. One important development is the fragmentation of consumer markets, which has increased the difficulties of communicating with customers through traditional channels. Market fragmentation may be partly explained by an increasing trend towards individualism, evidenced by people becoming more oriented towards selfexpression and seeking customised product offerings. The relevance of individualism to the current context is that companies need to communicate with market segments in more individual and focused ways. At the same time people may be more ready to accept, appreciate and respond to being targeted by relevant and individualised marketing (Evans, O’Malley \& Patterson, 1995: 17). Many forms of segmentation exist but, as marketing knowledge advances and competition increases, the need for more precise segmentation tools becomes greater (Mitchell, 1994: 4). The significant relationship found in this study proposes that direct marketers can use consumers' number of retail-credit accounts as a segmentation variable.

There are thousands of new customers entering the market every month, from people starting new businesses to young adults becoming eligible for credit for the first time. The finding of this study suggests that credit issuers should consider focusing their direct marketing offers at existing customers, instead of focusing the majority of their efforts on new customers. Issuers need to create new models to weed out unresponsive prospects from mailing lists. The trick is to isolate creditworthy customers who have not previously been flooded with offers, and issuers probably need new mailing lists and sources of data for prospects. The key is to find the balance between economies of scale and tailored marketing offers, because most of the prospect lists available to credit issuers are so overworked that it is becoming more costly to wring better results out of these lists (Fitzgerald, 2001: 53).

The present study has certain shortcomings that need to be kept in mind. The study was designed to address the relationship between retail accounts held and response rates. The purpose was not to make predictions, but rather to indicate whether a certain relationship exists. The study relates to one sample and the analysis is performed on one mailing campaign only. The study negates the effect on response rates of other factors such as offer design and creative elements. Future studies may wish to investigate the trend across different samples for the same organisation or the trend within samples across various organisations. Future research can focus on multiple regression analysis using combinations of variables that could affect response rate (including number of retail accounts held). Factor and cluster analysis are techniques that could also be considered to improve knowledge of market segments.

\section{Conclusion}

With declining customer loyalty, an ongoing decline in response-and-activation rates, and increased pressure on profit margins, some credit issuers, micro lenders and even some banking institutions are making an effort to target customers more effectively, and are retreating from their mass approach to direct mail. The problem of targeting points to the limits and shortfalls on what type of help is available through new approaches of segmentation. Many companies have been very successful in targeting existing clients rather than soliciting potentially new customers. Segmentation has traditionally divided customers either by user-characteristics or user-behaviour. While demographic information can help to classify and perhaps define the likelihood of purchasing, other data such as credit data may be needed to help marketers understand actual buying behaviour. Credit issuers are vastly improving their portfolio management in terms of building client retention and crossselling models, but the development of response models and 
list criteria still has a long way to go. The market is indeed saturated, but there is still plenty of room for growth if credit issuers take a strategic approach and find ways to avoid wasting money on repetitive and ineffective direct mail efforts.

\section{References}

Albro, W. \& Linsley, C. 2001. 'Credit card solicitations: Less for more’, Bank Marketing, 33(2): 11.

Bernstel, J.B. 2000. 'Direct mailstrom', Bank Marketing, 32(9): 28-31.

Dibb, S. 1998. 'Market segmentation: Strategies for success', Marketing Intelligence and Planning, 16(7): 394406.

DMA. Direct Marketing Association. 2000. What is the size and scope of direct marketing in South Africa. [online] URL:http://www.dma.org.za/industry faq.htm.

Evans, M., O'Malley, L. \& Patterson, M. 1995. 'Direct marketing: Rise and rise or rise and fall?', Marketing Intelligence and Planning, 13(6): 16-23.

Experian. 2004. Insource. [online] URL: http://www.experian.com/products/insource.html.

Fitzgerald, K. 2001. 'The enigma of mail', Credit Card Management, 14(3): 52-6.

Forcht, K.A. \& Cochran, K. 1999. 'Using data mining and datawarehousing techniques', Industrial Managament and Data Systems, 99(5): 189-96.

Hisey, P. 2000. 'A retail card rally', Credit Management, 13(2): 55-6.

Hoek, J., Gendall, P. \& Esslemont, D. 1996. Market segmentation - In search for the holy grail', Journal of Marketing, 2(1): 25-34.

Ibis, D. 1991. 'Cluster analysis targets prospects', Credit World, 80(2): 38-41.

Kaynak, E., Kucukemiroglu, O. \& Ozmen, A. 1995. 'Correlates of credit card acceptance and usage in an advanced developing Middle Eastern country', Journal of Services Marketing, 9(4): 52-64.

Lach, J. 2000. 'Maxed out', American Demographics, 22(6): 26-9.

Lamb, C.W.L., Hair, J.F., McDaniel, C., Boshoff, C. \& Terblanché, N.S. 2004. Marketing. Second South African edition. Cape Town: Oxford University Press.

Linsley, C. 2001. 'Credit-card solicitations: Doing less with more', Bank Marketing, 33(5): 11.

Lucas, P. 2000. 'The listlessness in prospect lists', Credit Card Management, 13(8): 33-42.
Martien, F.B. \& Morgan, C.W. 2002. 'Credit-card marketing: the enigma of channel choice', First Annapolis Navigator, August: 1-5.

Meadows, M. \& Dibb, S. 1998. 'Assessing the implementation of market segmentation in retail financial services', International Journal of Service Industry Management, 9(3): 266-85.

Mitchell, V.W. 1994. 'How to identify psychographic segments: Part 1', Marketing Intelligence and Planning, 12(7): 4-10.

Paden, N.L. 1996. 'Retail credit usage and relationship marketing', MCB Journal of Consumer Marketing, 13(20): $1-10$.

Schoenwald, M. 2001. 'Psychographic segmentation: used or abused?' , Brandweek, 42(4): 34-6.

Schultz, R. 2002. 'Credit card mailings hit record volume', Direct Newsline, 11 April. [online]

URL:http://industryclick.com.

Sharpe, D. L. 1997. 'Credit and debt portfolios of the young and old', Consumer Interests Annual, 43: 210.

Souccar, M.K. 2000. 'Mass-mailing misfires - still bedeviling card issuers', American Banker, 165(32): 1.

SARB. (South African Reserve Bank). 2004. Quarterly Bulletin, March: S-22.

Strumello, S.C. 2000. 'Study points out opportunity', Bank Advertising News, 24(9): 4.

Thomas, B. \& Housden, M. 2002. Direct marketing in practice. Oxford: Butterworth Heinemann.

Volman, B., Jordaan, Y. \& Bird, S. 2003. Contemporary direct marketing. Florida: Technikon SA.

Von Lieres, V. 2000a. 'Cost of high life is getting better', Bankmonitor, 6 Dec. [online]

URL:http://www.bankmonitor.co.za.

Von Lieres, V. 2000b. 'Woolies seals venture to launch credit card with Mercantile bank,' Bankmonitor, 10 Nov. [online] URL:http://www.bankmonitor.co.za.

Vriens, M., Van der Scheer, H.R., Hoekstra, J.C. \& Bult, J.R. 1998. 'Conjoint analysis for direct mail response optimization', European Journal of Marketing, 32(3-4): 323-39.

Willemse, I. 1990. Statistical methods and financial calculations. Cape Town: Juta \& Co. 